\title{
Mini Tinjauan Sistem Operasi Berbasis Perangkat Lunak Sebagai Pengelola Sistem Komputer
}

Operating System of Software Based in Review Mini as a Computer System Manager

\author{
Vinnia Risa Amalya (0305202132) \\ Pendidikan Matematika, FITK, UIN Sumatera Utara \\ Jl. William Iskandar Pasar V, Medan 20371, Indonesia \\ Email : vinniarisaamalya1@gmail.com
}

\begin{abstract}
$\underline{\text { Abstrak }}$
Sistem operasi merupakan perangkat lunak yang dapat mengelola seluruh sumber daya yang terdapat pada sistem komputer. Sistem operasi sebagai pengelola komputer juga memiliki sejarah perkembangan dan komponen dasar yang meliputinya. Artikel ini membahas sistem operasi yang memiliki berbagai macam bentuknya mulai dari Windows, Linux, UNIX, DOS sampai MacOS.
\end{abstract}

Kata $\mathbf{k u n c i}$ - Sistem operasi, perangkat lunak, pengelola sistem komputer

\begin{abstract}
$\underline{\text { Abstrack }}$
Operating system is a software who can manage resources in the computer systems. Operating siytem as a computer manage have history of development and the basic component to cover it. This article discuss about operating system have kind of form start from Windows, Linux, UNIX, DOS until MacOS.
\end{abstract}

Keywords - Operating system - software - the computer system manager

\section{A. PENDAHULUAN}

Dalam kehidupan saat ini, semua orang dari kalangan penjuru dunia baik pelajar maupun pekerja tidak akan pernah lepas dari komputer. Komputer bukan hanya kebutuhan dalam belajar maupun bekerja namun dapat membantu 
mengerjakan berbagai hal seperti menyimpan data, mengolah kata, bahkan membuat laporan.

Komputer dengan kecanggihan teknologinya tidak akan terlepas dari software karena tanpa software komputer hanyalah benda mati. Pada era teknologi ini, komputer bukan hanya sebagai alat bantu untuk mengerjakan tugas atau laporan, namun dengan adanya software seluruh pengguna dapat menikmati kecanggihan teknologi yang membantunya dalam hal apapun termasuk bisnis. Dalam dunia bisnis, software dapat digunakan sebagai pengolahan kata dan pengolahan data-data perkantoran.

Mungkin banyak yang tidak mengetahui dengan detail mengenai pengertian dari software. Software dapat diartikan sebagai perangkat lunak. Perangkat lunak ialah perangkat yang tidak memiliki batang tubuh atau rangka namun dapat dioperasikan.

\section{B. STUDI LITERATUR}

Sistem operasi adalah satu dari beberapa komponen utama dalam sistem komputer. Adapun beberapa komponen yaitu perangkat keras, perangkat lunak, dan pengguna. Perangkat atau hardware adalah sebuah benda yang dapat disentuh dan sumber daya untuk komputasi. Perangkat lunak atau software adalah sebuah sarana yang dapat menyampaikan ke hardware tentang apa saja yang dijalankannya. Namun dalam perangkat lunak ada perbedaan karena perangkat lunak adalah sebuah benda dua dimensi yang tidak dapat disentuh. Perangkat lunak dipilah menjadi dua unit yaitu sistem operasi dan program aplikasi.

Sistem operasi diartikan sebagai program yang mengelola software dengan memberikan landasan untuk aplikasi yang ada di tingkatnya, juga menghubungakan antara pengguna atau user dengan hardware. Sistem operasi mempunyai tugas yaitu mengontrol dan mengatur pekerjaan hardware dalam bermacam program aplikasi untuk berbagai pengguna.

Sistem operasi berguna sebagai coordinator computer agar dapat menjalankan program dengan benar. Sistem operasi juga sebagai pengatur untuk pengguna agar dapat mengakses sumber daya juga untuk menghindari 
permasalahan saat menggunakan sumber daya yang sama. (Ronal Watrianthos dan Iwan Purnama 2001, 1)

\section{METODOLOGI}

Peralatan dan bahan penilitian dalam penilitian ini ialah menggunakan Buku "Dasar-Dasar Komputer" yang ditulis oleh Bapak Yahfidzham, Buku Ajar "Sistem Operasi” yang ditulis oleh Bapak Ronal Watrianthos dan Iwan Purnama dan juga Buku "Pengantar Sistem Operasi Komputer" yang ditulis oleh sekelompok Masyarakat Digital Gotong Royong.

Dalam teknik pemilihan sumber artikel dan tulisan dilakukan suatu penyaringan sesuai dengan topik yaitu sistem operasi perangkat lunak komputer. Setelah menganalisa, mempelajari dan memahami isi bacaan dari beberapa literature barulah penulis membuat suatu kesimpulan dan inti sari yang akan dibahas pada artikel.

\section{PEMBAHASAN}

\section{Sejarah Perkembangan Sistem Operasi}

Sejarah perkembangan sistem operasi tidak bisa dilepas dari sejarah perkembangan komputer secara global. Komputer adalah suatu sistem maka dapat dibilang bahwa perkembangan sistem operasi sejalan dengan perkembangan hardware. Sejarah sistem operasi adalah berikut ini.

\section{- Generasi Pertama}

Sejarah sistem operasi pada generasi pertama terjadi pada tahun 1945 sampai 1955. Pada era tersebut computer tidak mempunyai sistem operasi. Sistem operasi dikerjakan secara langsung dan hanya dapat dipakai untuk melakukan berbagai macam proses perhitungan angka atau aritmatika.

\section{- Generasi Kedua}

Generasi ini terjadi pada tahun 1955 sampai 1965. Pada era ini computer juga belum difasilitasi dengan sistem operasi namun ada beberapa dasar sistem operasi yang ada seperti FMS dan IBSYS. 
- Generasi Ketiga

Generasi ketiga ini terjadi pada tahun berikutnya yakni 1965 sampai 1980. Sistem yang ada dalam computer berkembang dan mempunyai fungsi untuk melayani pengguna interaktif dan online. Sistem computer menjadi dua yakni multiuser dan multiprogramming. Pada generasi ini juga muncul sistem operasi UNIX.

- Generasi Keempat

Generasi keempat terjadi pada tahun 1980 sampai 1990 ditandai dengan bertambahnya keahlian komputer dan teknologi jaringan. Komputasi tersebar dengan teknologi yaitu sistem operasi yang dikhususkan untuk jaringan komputer.

\section{Layanan Sistem Operasi}

Sistem operasi memiliki beberapa layanan adalah sebagai berikut :

- Eksekusi program yakni sistem yang mampu dan bisa untuk membawa program ke memori dan mengoperasikan program.

- Operasi input/output yakni sistem operasi harus memberikan layanan mekanisme untuk menjalankan operasi input/output dengan nama pengguna.

- Sistem manipulasi berkas yakni program mampu untuk melakukan operasi pada berkas seperti membaca, mmenulis, membuat dan menghilangkan berkas tersebut.

- Komunikasi yakni sistem saling menukar data atau informasi antar proses yang ada dalam satu computer ataupun lebih.

- Deteksi error yakni memberikan penjagaan sistem yang stabil dengan menemukan kerrorran dalam hardware ataupun operasi.

Sistem operasi akan memberikan layanan dalam efesisensi pada penggunaan sistem yaitu sebagai berikut :

- Resource allocator yakni sistem operasi yang membagikan sumber daya ke pengguna - pengguna yang sedang menjalankan sistem pada saat yang sama.

- Proteksi yakni sistem operasi akan memberikan jaminan akses ke sistem sumber daya yang ditanggulangi. 
- Accounting yakni sistem operasi akan merekam beberapa kegiatan yang dilakukan pengguna dan alokasikan sumber daya yang dipakai dengan berdasarkan keadilan.

\section{Komponen Dasar Sistem Operasi}

Sistem operasi memiliki beberapa komponen yang mendasar untuk membantu pengoperasian yaitu sebagai berikut :

- Manajemen proses

Proses merupakan semacam program yang dieksekusi. Suatu proses tersebut perlu sumber daya dalam eksekusi yaitu CPU, memori, dll. Sistem operasi memiliki tanggung jawab untuk aktifitas yang berkaitan dengan manajemen proses.

- Manajemen memori utama

Memori merupakan sebuah penyimpanan data dari program. Memori juga penyimpanan yang bisa mengimbangi kecepatan kinerja tugas CPU. Sistem operasi memiliki tanggung jawab yang berkaitan dengan manajemen memori utama.

- Manajemen berkas atau file

Berkas adalah kelompok informasi yang berkaitan yang umumnya juga mengutarakan atau menyajikan program dan data. Dalam hal ini sistem operasi memiliki tanggug jawab yaitu menghapus atau membuat berkas, membuat atau menghapus direktori, dll.

- Manajemen Input atau Output

Dalam hal ini sistem input/output berisi sistem buffer, spooling, antarmuka devices-driver, dan menyajikan driver untuk melaksanakan operasi detail.

- Manajemen Penyimpanan Sekunder 
Penyimpanan sekunder adalah pernyimpanan yang bersifat permanen yang merupakan cadangan dari memori utama. Sistem operasi memiliki tanggung jawab dalam aktivitas yang berkaitan dengan manajemen penyimpnan ini yakni mengatur ruang kosong, menyediakan penyimpanan, dan perencanaan disk,

- Jaringan atau sistem terdistribusi

Sistem terdistribusi adalah sekelompok prosesor yang tidak dapat membagi memori. Semua prosesor mempunyai memori yang lokal pada masing masingnya. Sistem terdistribusi memberikan akses pengguna ke berbagai sumber daya. Akses itu memberikan dampak dalam peningkatan kecepatan komputasi dan penyediaan data.

\section{- Sistem Proteksi}

Proteksi terhubung dengan sistem untuk mengatur akses yang dikerjakan oleh program, pengguna, dan prosesor. Sistem proteksi diwajibkan untuk mmampu membedakan antara pemakaian yang sah dan tidak sah.

- Command - interpreter system

Dalam hal ini, sistem operasi menanti tugas atau instruksi dari pengguna yang biasa disebut dengan comman driven. Sebuah program yang menemukan tugas dan menerjemahkan keinginan pengguna biasanya disebut dengan commandline interper.

\section{Struktur Dasar Sistem Operasi}

Sistem operasi memiliki struktur dasar yang pernah ada dan digunakan yakni sebagai berikut :

\section{- Sistem monolitik}

Sistem operasi merupakan sekolompok langkah atau saluran yang jika dibutuhkan dapat saling dipanggil oleh saluran lain dalam sistem. Kelemahan dalam sisitem ini adalah percobaan dan penghapusan kesalahan lumayan susah karena tidak bisa disingkirkan dan disediakan, susah untuk mencadangkan 
pengamanan dan memiliki kerugian atau boros jika computer harus menggerakkan kernel monolitik yang besar yang seharusnya tidak memakai semua layanan yang ada di kernel. Keunggulan dalam sistem ini yakni layanan bisa dijalankan dengan cepat karena punya satu ruang alamat UNIX yang sampai sekarang masih berstuktur monolitik. Dalam hal ini, walaupun monolitik yakni semua komponen ataupun subsistem dalam sistem operasi yang ada di satu ruang alamat namun jika secara pembuatan adalah berlapis. Ada beberapa hal yang mempermudah dalam mengembangkan dan menguji UNIX yakni memakai konsep kemel loadable modules yaitu bagian kemel yang terpenting dan terletak di memori utama secara permanen, bagian modul yang bisa ditambahkan ke kemel jika diperlukan dan dilepas jika tidak digunakan dalam waktu jalan atau run time.

\section{- Sistem berlapis}

Sistem operasi dibuat secara berurut menurut lapisan - lapisan dan lapisan bawah menampung layanan dalam lapisan yang lebih atas. Ada keunggulana dalam sistem ini yakni mempunyai rancangan modular yang unggul yaitu sistem dipilah menjadi beberapa modul dan tiap -tiap modul dibuat secara sendiri sendiri. Tiap -tiap lapisan bisa dibuat, ditandai dan diuji secara sendiri - sendiri. Ada juga kelemahan yang terdapat dalam sistem ini yaitu kegunaan dalam sistem operasi wajib diberikan ke tiap - tiap lapisan secara cermat.

- Sistem dengan mesin maya

Mesin maya memiliki sistem timesharing yang berguna untuk memberikan kemampuan untuk multiprogramming dan perkembangan mesin dengan antarmuka yang lebih baik.

Adapun beberapa komponen dasar atau komponen utama yang ada dalam mesin maya yaitu control program yakni mengelola kegunaan prosessor, memori dan input atau output yang berkaitan langsung dengan hardware dan conventional monitor system yakni yang mengelola kegunaan dari proses penanganan informasi dan piranti. 
Ada beberapa keunggulan dalam mesin maya yakni memberikan keamanan yang sempurna untuk sistem sumber daya yang menjadikan masingmasing dari mesin virtual dibagikan ke mesin virtual lainnya dan peningkatan sistem dilakukan dalam mesin fisik dan tidak mengganggu operasi sistem yang biasa. Ada juga kekurangan dari mesin maya yakni konsep nya lumayan sulit memakaikan kebutuhan dan penggandaan yang sesuai dan tepat pada mesin yang seharusnya.

- Sistem client-service

Sistem operasi bisa dikatakan sekelompok proses dengan proses - proses yang dikelompokkan sebagai server dan client. Server yakni yang memberikan layanan dan client yakni yang membutuhkan layanan.

Proses client yang membutuhkan layanan dengan mengirim sinyal ke server dan menunggu jawaban. Server akan memberikan hasil dalam wujud pesan jawaban ke client setelah mengerjakan tugas yang diminta client. Server hanya melayani permintaan client dan tidak memulainya dengan obrolan client.

Ada beberapa kelebihan dari client-service yaitu peningkatan yang bisa dilakukan secara modular, kesalahan di salah satu subsistem tidak akan mengganggu subsistem lainnya dan sistem ini mudah disesuaikan untuk sistem tersebar. Ada juga kekurangan dalam sistem ini yaitu layanan yang dilakukan lumayan lambat, pengiriman pesan yang bisa menyebabkan bottleneck dan tidak semua tugas bisa dilakukan dalam tingkat pemakai.

- Sistem berorientasi objek

Sistem operasi berorientasi objek adalah sistem operasi yang disusunkan dibentuk dengan memakai objek. Hal itu ditujukan untuk mengambil keunggulan dari teknologi yang berorientasi objek.

Dalam sistem yang berorientasi objek, layanan diterapkan sebagai kelompok objek. Objek menyatukan struktur data dan sekelompok opetasi dalam struktur data tersebut. Setiap objek akan dialokasikan tipe yang menandai 
property objek yakni proses, berkas dan lainnya. Setelah operasi dimaksudkan dalam objek maka data yang dikumpulkan bisa diteruskan dimutasi.

Sistem ini memiliki keunggulan yakni terstruktur dan membagi antara layanan yang disiapkan dan implementasinya. Sedangkan kekurangannya adalah sistem operasi MS Windows NT sudah mengambil sebagian teknologi yang berorientasi objek namun tidak secara keseluruhan.

- Sistem kernel mikro

Kenel mikro merupakan sistem yang bisa menghapus beberapa komponen yang tidak dibutuhkan dari kernel dan berguna untuk meluangkan fasilitas komunikasi antara program client dan berbagai penyediaan yang dilakukan pada ruang pengguna.

Ada kelebihan dari kernel mikro yakni memudahkan untuk peningkatan sistem operasi dan memudahkan untuk diganti menjadi bentuk arsitektur baru. Sedangkan kekurangannya adalah performa akan menurun selagi meningkatnya beberapa fungsi yang digunakan.

\section{Macam - Macam Sistem Operasi}

Ada beberapa sistem operasi saat ini yang digunakan adalah sebagai berikut :

\section{- Microsoft Windows}

Microsoft windows merupakan sistem operasi yang beroperasi dalam mesin mikro computer seperti personal computer, laptop, dan sebagainya. Sistem operasi windows ini telah ada dari tahun 1981 dan sudah memiliki banyak peningkatan dalam kemampuan di komputer dan berbagai macam hardware yang disambungkan ke sistem komputer.

Sistem operasi windos dibuat oleh Microsoft yakni perusahaan yang dimiliki Mr. Bill Gates. Dalam sistem operasi windows ini memiliki versi yang terbaru dan sudah berkembang di pasaran yakni Windows Seven untuk beberapa 
mikro komputer. Sistem operasi dari windows versi sebelumnya adalah Windows 98, 2000, NT, XP dan Vista.

Ada beberapa kelebihan pada windows yakni bisa dijalankan melebihi satu aplikasi secara bersamaan, bisa membuka file lebih dari satu dengan bersamaan juga, bisa dengan mudah membagi dari data aplikasi yang lainnya, memiliki banyak aplikasi yang kompatibel, pemula yang awam mengenai komputer dapat menjalankannya dan windows memiliki banyak dukungan yaitu hardware dan software.

Meskipun banyak kelebihan dari windows, sistem ini masih memiliki beberapa kekurangan yakni memiliki sistem file yang lumayan rumit seperti jika mengunduh aplikasi maka sistem file pengintegrasian akan dipindahkan ke tempat C namun aplikasi yang diunduh tersebut berada di tempat lain, memiliki dampak akan kecanduan dalam menggunakan produk Microsoft, muatan hardisk yang diperlukan lumayan besar, pengamanan yang lemah dan mudah dibobol para hackers, memerlukan fisik memori yang besar, memerlukan prosesor yang memiliki kecepatan yang tinggi, memiliki harga yang mahal pada license dan memerlukan perawatan yang berkelanjutan dan prosedur yang harus sesuai dengan petunjuk yang ada saat memakainya.

- Linux

Linux muncul dengan diawali oleh seorang mahasiswa yang bernama Linus Benedict Torvalds di Helsinki. Ia menginginkan sebuah sistem operasi yang sehandal UNIX namun memiliki biaya semurah PC.

Pada pertengahan tahun 1991 Linus memulai untuk mengumpulkan beberapa inofmrasi dan menyelediki solusi untuk memunculkan UNIX pada PC. Linux dihadirkan dengan sistem operasi yang menggunakan Internet untuk berkomunikasi dan ditingkatkan dengan memakai konsep open source. Dalam hal ini, Linux dikembangankan melalui semua orang yang memiliki keinginan untuk meningkatkan dan mengembangkannya. Dengan konsep tersebut, Linux menimgkat dengan sangat cepat. Konsep open source ini dinamakan General 
Public License atau disebut dengan GPL oleh GNU yakni suatu lembaga yang memberikan dan memperjuangkan untuk membebaskan dalam penggunaan software.

Linus Torvalds mendirikan sistem operasi sehebat UNIX dengan bertemu Richard M Stallman yakni menggunakan konseo Open Sorce yang berlisensi General Public License yang melahirkan Linux. Ada beberapa sistem operasi yang berbasisi Linux seperti Redhat, Fedora, Blankon, Debian, Kubuntu, Ubuntu, Knopix, Gento, Slakewake, xnuxer yang dibuat oleh Dani Firmansyah yakni seorang warga negara Indonesia yang membobol server KPU, Flax dan lainnya.

Linux memiliki banyak keunggulan yakni lisensi yang free, bisa berhubungan dengan sistem operasi lain yang caranya dengan penyesuaian file sistem, network dan simulasi pada sistem operasi, dengan adanya virtual memory menjadikan linux punya keahlian untuk melayani program - program yang lebih, bisa berlangsung dari computer 286 XT shingga mesin sebesar Beowulf Clusters, jika dibangun dengan benar maka bisa berjalan sangat stabil sampai hardwareya rusak, menurunkan tradisi UNIX dengan menunjang adanya izin file yang dapat menahan jika diubah atau dihapus yang bisa mencegah adanya virus, cepat memperoleh solusi jika menemui bug karena ada dukungan dari ribuan programmer di pelosok dunia dan memiliki paket Linux yang artinya satu yang kesatuan yang mana bergantung dengan keinginan pengguna dan telah banyak didikung perusahaan hardware ataupun software di seluruh dunia.

Dengan banyaknya keunggulan di atas, Linux masih tetap memiliki kekurangan yakni sistemnya lumayan sulit untuk digunakan bagi pengguna awam komputer, aplikasi yang disediakan masih sedikit, sistem operasinya tidak seluruh GUI atau disebut dengan Grapicha User Interface yang menggunakan X-windows seperti GNOME dan memiliki perbedaan nama distro satu dengan lainnya seperti Yaz.tar.gz.rpm.krpm.deb dan lainnya.

- UNIX 
Unix merupakan sebuah sistem operasi yang awalnya berkembang pada tahun 1965 melalui laboratorium Bell, AT \& T yang ditingkatkan oleh Ken Thompson dan Dennis Ritchie. Unix memiliki nama lain sebelum dikembangkan yakni Multics atau Multiplexed Information and Computing Service.. Unix dirancang dengan tujuan untuk bisa melakukan multi tasking, portable dan bisa digunakan dengan lebih dari satu pengguna. Pengembangan UNIX semuanya didanai oleh Departemen Pertahanan Amerika atau disebut dengan DARPA.

Kelebihan dari UNIX adalah gratis, dapat dijalankan dengan banyak tugas secara bersamaan dalam waktu yang sama atau bisa disebut dengan multitasking, sistem file yang teratur, portabilitas dan mempunyai performa yang lebih bagus Windows NT. Sedangkan dengan kekurangan dari UNIX adalah tidak cocok untuk pengguna biasa karena dalam menjalankan sistem ini lumayan sulit, memilki penampilan yang kurang menarik dan memerlukan memori yang besar.

- MacOS

MacOS yang kepanjangannya adalah Machintosh Operating System merupakan sistem operasi yang hanya ada dalam komputer Apple. MacOS dikeluarkan pada tahun 2001 dan semenjak itu popular di kalangan para pengguna.

Kelebihan dari macOS adalah lebih stabil, tampilannya bagus untuk keperluan multimedia, mempunyai proteksi yang tinggi dan tidak gampang diertas sertan aman dari virus. Sedangkan kekurangan dari macOS adalah harganya lumayan mahal, tidak terlalu optimal untuk game dan tidak memiliki konsep open source.

\section{- Sistem Operasi Disk}

Sistem operasi disk atau disebut dengan DOS adalah sistem operasi yang biasanya dipakai untuk mengatur seluruh sumber daya yang berada dalam komputer. Sistem operasi disk digunakan pada perangkat penyimpanan disk seperti floody disk, hard disk driva atau disk optik. Sistem operasi disk harus memberikan persediaan sistem file untuk mengelola, membaca dan menulis file 
dalam disk penyimpanan. Sistem operasi disk juga tersedia untuk mainframe, minicomputer, mikroprosesor dan komputer rumahan yang umunya dimuat dari disk itu sendiri sebagai salah satu bagian dari proses boot.

Adapun kelebihan pada sistem operasi disk yakni sistem ringan yang tidak akan mengisi banyak memori, ukurannya kecil dan mempunyai kompatibititas yang tinggi. Sedangkan kekurangan pada sistem operasi disk adalah belum terdapat adanya antar muka dan arahan pada sistem ini hanyalah berbentuk tulisan tidak ada grafis.

\section{E. KESIMPULAN}

Sistem operasi merupakan sebuah sistem yang mengelola atau mengatur sumber daya yang ada pada komputer. Perkemmbangan sistem operasi dimulai dari generasi pertama sampai generasi keempat yang terjadi pada tahun 1945 sampai 1990.

Sistem operasi memiliki layanan sebagai pengelola komputer yaitu mengeksekusi program, mengoperasikan input/ouput, memanipulasi berkas, berkomunikasi dan mendeteksi error yang sangat memberikan keuntungan pada komputer.

Sistem operasi juga memiliki komponen yang membantu kinerjanya yakni manajemen proses, manajemen berkas/file, manajemen input/ouput, manajemen penyimpnanan sekunder, sistem terdistribusi, proteksi atau perlindungan dan command.

Berbagai macam sistem operasi yang dipakai sampai saat ini adalah Windows, MacOS, Linux, UNIX dan DOS. Windows memiliki keunggulan bisa dijalankan melebihi satu aplikasi secara bersamaan dan bisa membuka file lebih dari satu dengan bersamaan juga. MacOS yang hanya bisa dipakai pada komputer Apple saja memiliki tampilan yang baik untuk keperluan multimedia. Linux memiliki lisensi yang free dan bisa berhubungan dengan sistem operasi lain dengan cara penyesuaian file sistem. UNIX merupakan sistem operasi yang dapat dijalankan dengan banyak tugas secara bersamaan atau disebut dengan multitasking. DOS yang memiliki sistem ringan dan tidak akan mengisi banyak memori. 


\section{F. DAFTAR PUSTAKA}

Aulia Rahma Lubis, Perangkat Lunak Komputer, dikutip dari https://osf.io/dp98b/ Watrianthos, Ronal dan Iwan Purnama. 2018. Sistem Operasi. Ponorogo : Uwais Inspirasi Indonesia

Yahfizham, 2019. Dasar-Dasar Komputer. Medan : Perdana Publishing Yuliarso, Dhani dkk. 2005. Pengantar Sistem Operasi Komputer. Depok : Fasilkom Universitas Indonesia

\section{BIODATA DIRI}

Vinnia Risa Amalya. Saat ini seorang mahasiswa aktif pada program studi S1 Pendidikan Matematika, Fakultas Ilmu Tarbiyah dan Keguruan di Universitas Islam Negeri Sumatera Utara, Medan. 